\title{
Model Development of the Coastal Tourism Community Nursing through Coastal Health Post (Poskespan) to Increase Tourist Satisfaction in Bali Province
}

\author{
Komang Ayu Henny Achjar ${ }^{1}$, Junaiti Sahar ${ }^{2}$, Sabarina Prasetyo ${ }^{3}$, Jajang Gunawijaya ${ }^{4}$ and Lita Heni Kusumawardani ${ }^{*}$ \\ ${ }^{1}$ Department of Community Nursing, Health Polytechnic, Ministry of Health, Denpasar, Bali, Indonesia \\ ${ }^{2}$ Department of Community Nursing, Faculty of Nursing Science, Indonesia University, Campus UI, Depok, Indonesia \\ ${ }^{3}$ Department of Public Health, University of Indonesia, Campus UI Depok, Indonesia \\ ${ }^{4}$ Department of Anthropology FISIP, University of Indonesia, Campus UI Depok, Indonesia \\ ${ }^{5}$ Department of Nursing, University Indonesia, Indonesia \\ *Corresponding author: Lita Heni Kusumawardani, Department of Nursing, University Indonesia, Indonesia, Tel: +6285713991875; E-mail: \\ litahenikusumawardani@gmail.com
}

Received date: May 16, 2018; Accepted date: May 24, 2018; Published date: June 01, 2018

Copyright: ( 2018 Achjar $\mathrm{KAH}$, et al. This is an open-access article distributed under the terms of the Creative Commons Attribution License, which permits unrestricted use, distribution, and reproduction in any medium, provided the original author and source are credited.

\begin{abstract}
Satisfaction is a feeling perceived by the customer, achieved by comparing perceived performance with customer expectations of a particular product/service. The satisfaction of the service is judged by the quality of service provided. Satisfaction with the nursing service of the coast tourist community is judged by the quality of service provided during the tourist visits. Tourism research on nursing tourism is still limited publication; in fact it has not been done in Indonesia. Whereas the Community Health Care Services program has been declared since the 1970s, but the focus of the tourist community has not been untouched. Studies related to community nursing in beach tourism have not been done until now. Moreover, there are no local government regulations, cross-sectoral cooperation on coastal accident management efforts at the beach to improve tourist safety. This study aims to develop coast tourist community nursing model through coastal health post (Poskespan) to improve the safety of tourists at the beach of Badung Regency, Bali Province. Quantitative research design or quasy experiment is done with pre post test with control group design. Cluster sampling technique. The respondents of the intervention group were tourists visiting the eight sub-districts of Kuta Center, Badung Regency, which contained three coastal health posts (Poskespan Kuta, Legian, Seminyak) amounting to 360 respondents. Tourists who visit the beach in which there is no coastal health post as a control group, amounting to 360 people. Based on the results of the research, it is known that there is an influence of the development of nursing model of coastal tourist community through coastal health post for the safety of tourists. Therefore, it is hoped that coastal health post model can be one of the health efforts of the community (UKBM) in a special group of coastal communities in Indonesia such as poskestren which is used as the guide of UKBM to the group especially pesantren or poskesdes community in villagers. Poskespan model is also built like the concept of UKBM which is also available such as in other areas of Indonesia by involving personal of Poskespan namely surf lifesaving association, and the involvement of community health center personnel for activities outside the community health center building.
\end{abstract}

Keywords: Coastal health post; Satisfaction; Tourist

\section{Background}

Indonesia is an archipelagic country surrounded by beaches, and it is a great potential for the development of tourism services. This is supported also by the government program on maritime priority. The beach becomes one of the priority tourism services. Beach in Indonesia is one of the most visited tourist services by tourists both domestic and foreign. The number of foreign tourist arrivals to Indonesia until December 2017 reached 1,147,031 with a target of $30 \%$ of tourists enjoying coastal tourism [1]. The beauty of Indonesia's coast is a tourist attraction, but it is still necessary efforts to provide health insurance against the risk of beach accidents.

Visits of foreign tourists to Indonesia, through three main gates are Bali 26.79\%, Jakarta 18.78\%, Batam 16.81\% [1]. According to Okkisafire, tourists who visit Indonesia in 2011, as many as 90 percent of tourists visit Bali. Bali is one of the favorite beach resorts in
Indonesia. Foreign and domestic tourists make Bali beaches as a place for swimming, sightseeing and water sports such as surfing, diving and snorkeling or just relaxing to enjoy the scenic beauty [2]. Activities undertaken by tourists during a tour of this beach can cause physical health problems, psychological, socio-cultural.

The risk of accidents occurring in coastal tourism can actually be reduced through the prevention of accidents risk in order that they don't increase through primary prevention, one of them through the provision of health education related to the risk of accidents on the beach and how to prevent it. In addition, beach accidents can be reduced so that cases do not gain weight through secondary prevention, by providing immediate measures such as early detection of health disorders of tourists and referral cases to health services. Primary prevention and secondary prevention of tourists and communities in coastal special areas can be performed by health personnel and become the authority of health workers assigned to the coastal health center, one of the roles of community nurses $[3,4]$. 
Activities undertaken by community nurses in interacting with tourists at the beach, becomes the domain of community health nursing in a special area at the beach. Focused service is dedicated on population risk to possible health problems. Nursing that has an area of competence concerning the coastal community is community health nursing.

The satisfaction of tourists is an important element in evaluating the quality of coastal tourism nursing services. Satisfaction with the nursing service of the coastal tourism community is judged by the quality of service provided during the tourist visits. Satisfaction is a subjective assessment of a person to the service he received. This is supported by Lazzeretti [5], which explains that tourist satisfaction depends not only on the experience, but also for other factors such as safety, sanitation and health. The results of research conducted by Kantawateera [6], said that community satisfaction is related to government policy in satisfying the society. Similar research on measurement of service quality proved to be related to satisfaction, and satisfaction has a positive relationship with return visits [7].

Based on the conditions described above, the use of coastal tourism through community capacity development, partnership and empowerment is strongly influenced by the involvement of the health, tourism and local government sector. Up to now, the partnership between the three related sectors in coastal tourism services has not been optimal yet, each performing its role but its synergy has not been optimal yet. Therefore, handling integrated coastal tourism is a thing to be thought together. The existence of coastal communities contributed to the successful use of coastal tourism, but their understanding to provide services is still low. Concern is only dedicated on the aspect of economic benefits itself, but it has not been balanced with the aspect of customer satisfaction

\section{Formulation of the Problem}

Characteristics of coastal tourism in Bali include tours that focus on natural beauty, open to the public, mass tourism (mass tourism) that involves the mass of people who go to a popular tourist destination. Some mass tourism activities include sunbathing on popular beaches such as Bali. Tourists do not all master the special skills of nature, local tourists and foreign tourists with different cultures, plus the density of people in limited locations, directly and indirectly have special problems related to health and tourism. Various articles that are available is just a little explaining about coastal tourism that pays attention to the importance of prevention related tourism user satisfaction. In order to ensure the satisfaction of tourists, it is necessary to prevent the risk of beach tourism injury, the handling of tourist accidents cases in coastal tourism, the involvement of stakeholder role in coastal tourism nursing service through tourism service partnerships, health offices, local government and local organizations. Therefore, nursing model is needed on coastal tourist community including community capacity building, empowerment and partnership to solve the problems of tourists in coastal tourism.

The nursing model of the coastal tourist community through Poskespan is one of the service activities provided for the tourists who visit the beach related to the prevention of the risk of injury and the handling of accident cases at the beach. This model is very suitable for beach tourism in Bali that is massive tourism, because of the high risk of tourist health during the tour of the beach, the high number of tourist visits especially during the holidays, tourists with different cultures and characters, tourists only focus on the natural beauty without thinking of the health risks encountered while doing beach tours.

\section{Method}

The research design that is used in this study used quantitative research study quasy experiment with study design of pre posttest with control group design. The test is conducted to the tourists to measure the safety of tourists in which before and after the intervention, it is provided by the nursing model of coastal tourist's community nursing through coastal health station (Poskespan).

The population in this study is all tourists who are in 24 coastals in Badung Regency of Bali Province. The sample in this study is the tourists who had made a visit at the beach area of Badung regency of Bali Province and they are willing to be respondents. The sampling technique used in this study is cluster sampling. The sample (tourists) sampling in this study used simple random sampling. The correspondent of the intervention group is the tourists who visited the eight beaches of Kuta Center, sub-district of Badung Regency which have three beaches health stations (Poskespan Kuta, Legian, Seminyak) amounted to 360 respondents. Tourists who visit the beach, in which there is no poskespan as a control group, amount to 360 people.

Study time was conducted for 6 months through two stages: model intervention stage (0-3 months after model intervention) and counseling stage (4-6 months after model intervention). The test results is concluded that the data is not normally distributed, therefore it applied non parametric statistical test of Wilcoxon and MannWhitney. Multivariate analysis used General linier Model Repeated Measure test (GLM-RM) [8].

\section{Results and Discussion}

\section{Tourist characteristics based on treatment group}

Characteristics of tourists in this study can be seen from the differences in education, sex and frequency of visits in the coastal of Badung Regency. The following describes the characteristics of tourists based on education, sex and frequency of visits as shown in Table 1 below.

Based on Table 1, it is explained that the average number of tourist visits to the beach in the last five years in the intervention group before being given model intervention of poskespan was 4.48 visits, 3.39 visits in the intervention group after 3 months of treatment and 6.68 visits in the intervention group after 6 months treatment. While the mean of control group visit to beach before treatment 6.01 times in the last five years, 6.12 times in control group after 3 months treatment and 2.71 times in control group after 6 months treatment. The results of the analysis showed that there was a different frequency of visits between the intervention group and the control group at all-time measurements with $<0.05$.

\begin{tabular}{|l|l|l|l|}
\hline Variable & Intervention & Control & p value \\
\hline
\end{tabular}


Citation: Achjar KAH, Sahar J, Prasetyo S, Gunawijaya J, Kusumawardani LH (2018) Model Development of the Coastal Tourism Community Nursing through Coastal Health Post (Poskespan) to Increase Tourist Satisfaction in Bali Province. J Health Educ Res Dev 6: 262. doi: $10.4172 / 2380-5439.1000262$

Page 3 of 5

\begin{tabular}{|c|c|c|c|c|c|c|c|}
\hline & Mean & \multicolumn{2}{|l|}{ Sd } & Mean & \multicolumn{2}{|l|}{ Sd } & \\
\hline \multicolumn{8}{|l|}{ Frequency Visits } \\
\hline -Before intervention & 4.48 & \multicolumn{2}{|l|}{3.437} & 6.01 & \multicolumn{2}{|l|}{3.568} & 0 \\
\hline-3 months of intervention & 3.39 & \multicolumn{2}{|l|}{2.349} & 6.12 & \multicolumn{2}{|l|}{5.485} & 0 \\
\hline-6 months of intervention & 6.68 & \multicolumn{2}{|l|}{3.477} & 2.71 & \multicolumn{2}{|l|}{5.485} & 0 \\
\hline \multirow[t]{2}{*}{ Variable } & \multicolumn{3}{|c|}{ Intervention (amount. \%) } & \multicolumn{3}{|c|}{ Control (amount. \%) } & $p$ value \\
\hline & $<$ SMA & SMA & $>S M A$ & $<$ SMA & SMA & $>$ SMA & \\
\hline \multicolumn{8}{|l|}{ Education } \\
\hline - Before intervention & $18(15)$ & $95(79.2)$ & $7(5.8)$ & $19(15.8)$ & $90(75)$ & $11(9.2)$ & 0.000 \\
\hline-3 months of intervention & $10(8.5)$ & $62(51.7)$ & $48(40)$ & $15(12.5)$ & $73(60.8)$ & $32(27)$ & 0.011 \\
\hline-6 months of intervention & $29(24.7)$ & $53(44.2)$ & $38(32)$ & $16(13.4)$ & $79(65.8)$ & $25(21)$ & 0.000 \\
\hline \multirow[t]{2}{*}{ Variable } & \multicolumn{3}{|c|}{ Intervention (amount. \%) } & \multicolumn{3}{|c|}{ Control (amount. \%) } & $p$ value \\
\hline & $M$ & \multicolumn{2}{|l|}{ W } & $M$ & \multicolumn{2}{|l|}{ W } & \\
\hline \multicolumn{8}{|l|}{ Sex } \\
\hline - Before intervention & $54(45)$ & \multicolumn{2}{|l|}{$66(55)$} & $53(44.2)$ & \multicolumn{2}{|l|}{$67(55.8)$} & 1.000 \\
\hline-3 months of intervention & $70(58.3)$ & \multicolumn{2}{|l|}{$50(41.7)$} & $59(49.2)$ & \multicolumn{2}{|l|}{$61(50.8)$} & 0.104 \\
\hline-6 months of intervention & $74(61.7)$ & \multicolumn{2}{|l|}{$46(38.3)$} & $81(67.5)$ & \multicolumn{2}{|l|}{$39(32.5)$} & 0.418 \\
\hline
\end{tabular}

Table 1: Tourists' characteristics of intervention and control group $(\mathrm{n}=720)$.

Differences of tourists satisfaction rate between intervention group and control group

Tourists' satisfaction before model intervention, 3 months and 6 months after intervention based on treatment group, is described as Table 2 below.

\begin{tabular}{|c|c|c|c|c|c|}
\hline Measurement time & Mean & Median & Sd & Min-Max & $P$ value \\
\hline \multicolumn{6}{|l|}{ Before treatment } \\
\hline -intervention group & 89.32 & 91.00 & 15.459 & $44-120$ & \multirow{2}{*}{0.000} \\
\hline -Control Group & 80.49 & 83.00 & 12.455 & 44-105 & \\
\hline \multicolumn{6}{|c|}{3 months of intervention } \\
\hline -Intervention group & 112.76 & 115.00 & 8.281 & $89-123$ & \multirow{2}{*}{0.000} \\
\hline -Control group & 75.95 & 76.00 & 10.927 & 44-101 & \\
\hline \multicolumn{6}{|c|}{6 months of intervention } \\
\hline -intervention group & 104.11 & 106.00 & 10.295 & $72-123$ & \multirow{2}{*}{0.000} \\
\hline -Control group & 70.13 & 69.00 & 8.955 & $49-90$ & \\
\hline
\end{tabular}

Table 2: Tourists' satisfaction based on measurement time $(n=720)$.

Based on Table 2 it was found that the average value of the intervention group's customer satisfaction before the presence of poskespan was 89.32 and increased the average value of satisfaction after three months of model intervention (112.76) and 104.11 after six months of model intervention. While the mean value of control group satisfaction before the existence of poskespan is 80.49 and decreasing the mean value of satisfaction after three months intervention (75.95) and the lowest value after six months intervention model (70.13). The results showed that there was difference of satisfaction level between intervention group and control group at all measurement time, with $\mathrm{p}$ value $<0.05$.

The result of analysis used General Linear Test of Repeated Measure Model (GLM-RM) on the variable of tourist satisfaction score measured repeatedly, statistically. The nursing model of coastal tourist community through coastal health station effectively increases the score of tourist satisfaction. There was a difference in the score of each group's customer satisfaction based on measurement time with $\mathrm{p}$ value 0.000 .

The intervention group tourist satisfaction score before intervention was seen to increase for up to three months after the model intervention and subsequently decreased in the six-month model intervention. While the control group continued to experience a decrease in satisfaction scores in the intervening three months and the lowest at six months after the model intervention was given. Baseline of intervention group tourist satisfaction score before being given intervention model is higher than control group satisfaction. The intervention group's tourist satisfaction score experienced the highest sharp rise in the three months after the model intervention was given.

There was a difference of tourists satisfaction score between the intervention group and control group at all time of treatment with group intervention 33.975 (group satisfaction level 34 points is higher than control group). It can be concluded that there is influence of 
Citation: Achjar KAH, Sahar J, Prasetyo S, Gunawijaya J, Kusumawardani LH (2018) Model Development of the Coastal Tourism Community Nursing through Coastal Health Post (Poskespan) to Increase Tourist Satisfaction in Bali Province. J Health Educ Res Dev 6: 262. doi: $10.4172 / 2380-5439.1000262$

Page 4 of 5

nursing model of coastal tourist community through healt station in beach (poskespan) to the level of satisfaction of tourists, described as Figure 1 below.

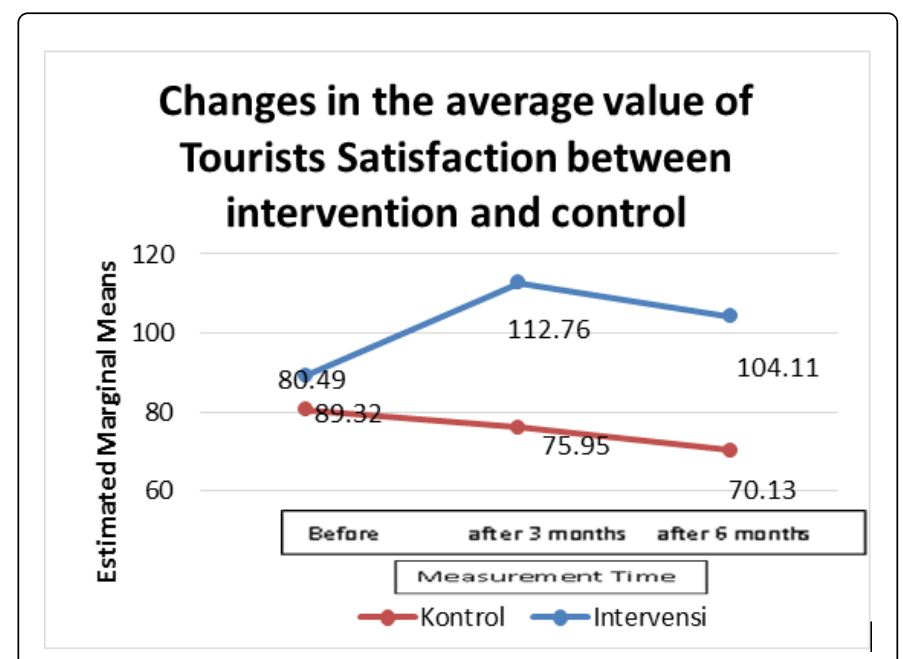

Figure 1: Tourists' satisfaction based on measurement time.

Measurement time has a significant difference in the rate of satisfaction of tourists with $\mathrm{p}$ value 0.000 . The interaction between group and time of measurement significantly affects the difference in the level of tourist satisfaction with the degree of significance of 0.000 . Intervention model of coastal tourist community nursing through health station in beach (poskespan) has contributed $64 \%$ to the satisfaction of tourists who visit the beach in Badung regency $\left(\mathrm{R}^{2}=0.646\right)$.

\section{Differences in tourists' satisfaction before and after the poskespan model intervention}

The difference in the satisfaction of the travelers before and after being given the intervention of the Poskespan model, in the intervention group and the control group, is described as Table 3 below.

\begin{tabular}{|l|l|l|l|l|l|l|}
\hline \multirow{2}{*}{ Variable } & \multicolumn{3}{|l|}{ Intervention } & \multicolumn{3}{l|}{ Control } \\
\cline { 2 - 7 } & Mean & Sd & pvalue & Mean & Sd & pvalue \\
\hline Satisfaction \\
\hline- -Before & 89.32 & 15.459 & & 80.49 & 12.455 & \\
\hline-3 months & 112.76 & 8.281 & 0.000 & 75.95 & 10.927 & 0.004 \\
\hline-6 months & 104.11 & 10.295 & 0.000 & 70.13 & 8.955 & 0.000 \\
\hline
\end{tabular}

Table 3: Differences of traveler's satisfaction before and after given intervention model of Poskespan ( $\mathrm{n}=720)$.

Table 3 shows that there was an increase in the average of the intervention group's tourist satisfaction before and after 3 months of intervention by the Poskespan model, and there was a decrease in satisfaction after 6 months of model intervention. While in the control group, there was a decrease in the satisfaction of tourists before and after 3 and 6 months of model intervention. The result of statistical test shows that there is difference of traveler's satisfaction before and after 3 months being given intervention of Poskespan model in both groups that is $\mathrm{p}$ value $<0.05$. There were also differences of traveler's satisfaction before and after 6 months intervention of Poskespan model in both groups, $\mathrm{p}$ value $<0.05$.

These results suggest that the Poskespan model intervention is crucial for increasing tourist satisfaction. The perception of tourists on the existence of Poskespan is very influential on the satisfaction of tourists related to the services provided. Tourists who have high knowledge tend to have a broader insight and understanding of information as well as about the existence of poskespan for the safety of tourists during a visit to the beach. Knowledge of tourists also affect the perception of tourists related to the importance of health centers for the prevention of injury risk and the handling of cases of accidents on the coast through the role of poskespan cadres, namely balawista. This condition is similar with the results of research Rahman et al. [9], which says that the perception of influence on the intention of visiting someone to the service of center(s) for pre-and postnatal health care and information for women and for children under five, respondents who have good perception tend to have a high intention to the existence of posyandu.

The satisfaction of tourists during a tourist visit is influenced by how much support of stakeholders and the community around the tourist attraction. Tourism sustainability greatly determines how satisfied the tourists are during a visit to a tourist attraction so that will affect the next visit. This condition is stated by the research results Othman [10], states that community-based tourism plays a very important role in determining the success of tourism development. Research of Guzman et al. [11] also stated that community support is one of the principles to ensure the successful development of tourism. Development of community-based tourism can create jobs and foster welfare for people around tourism. Othman's et al. [10], Widowati says that community support and involvement is an important factor determining the success and failure of tourism development. Also the results of Nurhidayanti's [12] suggests that factors that influence the successful implementation of tourism are the role of government, natural resource wealth, local cultural strength, openness to information, environmental conditions.

Intervention model of coast community nursing service through Poskespan has contributed to the happening of the level of customer satisfaction. According to the researcher, the increase of tourist satisfaction score along with the increase of balawista behavior happened especially on the 3rd month after intervention of Poskespan model. The decrease in the score of tourist satisfaction also coincided with the resumption of balawista behavior score at month 6 after being given intervention model. This has something to do with how the balawista provides services to tourists related to the prevention of the risk of injury in the form of safety counseling, quick assessment to surfers, as well as the handling of beach accident cases, case referral activities, case reporting records. This is in accordance with the results of research Rad et al. [13], who said that there is a positive relationship between assurance, empathy, responsiveness, reliability of patients who receive medical tourism services to the level of satisfaction. It is said that the attitudes and perceptions of patients on the skills of officers in meeting their psychological needs greatly affect patient satisfaction with the services provided. Also how the officers provide sufficient information, communication with the patient, and the empathy of the officer to the patient, patient care is reduced and impact on patient satisfaction. This is in line with the results of research Helmy [14], the quality of officers become a key element in the success of medical 
Citation: Achjar KAH, Sahar J, Prasetyo S, Gunawijaya J, Kusumawardani LH (2018) Model Development of the Coastal Tourism Community Nursing through Coastal Health Post (Poskespan) to Increase Tourist Satisfaction in Bali Province. J Health Educ Res Dev 6: 262. doi: $10.4172 / 2380-5439.1000262$

Page 5 of 5

tourism. Skills development programs such as communication skills, public relations, language skills, time management are required.

According to the researcher, the satisfaction of the tourists toward the intervention service of Poskespan model is influenced by various factors, namely the behavior of balawista as cadre of Poskespan, also the behavior of the nurses who served in poskepan in providing services related to the prevention of the risk of injury and the handling of accident cases at the beach. How nurses and balawista communicate to local and international tourists. This is in line with the results of research Taie [15], Reliability officers in providing services is the most important service components for customers. Quality of service is required in terms of providing reliable and accurate information by improving communication skills. According to the results showed that officers need to improve communication skills to provide explanations to patients before providing nursing care. Knowledge, courtesy, confidence, trust, and skill of the officer can increase patient satisfaction. According to Platonova et al. [16], to increase customer satisfaction requires empathy which refers to the care and attention of officers to patients such as ease of communication. The ability to communicate in English can be a barrier between officers and international patients [15].

Satisfaction of tourists during a visit to the beach became a benchmark of the success of the services provided. Services in accordance with the expectations of tourists are expected by tourists visiting the Badung district beach. This is supported by research results Poramaphorn [15], which explains that customer satisfaction is one important factor and become the best indicator for service. Satisfaction becomes one of the keys in maintaining the sustainability of the program and demonstrating the success of the service it receives. Poramaphorn [15] also found the same result that patients will choose a service where they feel comfortable, confident and recover well from their illness.

\section{Conclusion}

Poskespan model proved to affect the satisfaction of tourists. Intervention of coastal tourist community by nursing model through Poskespan has contributed to the happening of the level of customer satisfaction [16-19]. The perception of tourists on the existence of Poskespan is very influential on the satisfaction of tourists related to the services provided. Satisfaction of tourists during a visit to the beach became a benchmark of the success of the service poskespan given. Services that match the expectations of tourists are expected by tourists visiting the beach in Badung regency, Bali.

\section{Suggestion}

Based on the results of the research, the effective model of poskespan can increase the satisfaction and safety of tourists visiting the beach and proven to be effective in increasing the balawista behavior in preventing the risk of injury and increasing the case of beach accidents. So hopefully this Poskespan model can be used as one of the health efforts of the community (UKBM) in a special group of coastal communities in Indonesia. Poskespan model is also built like the concept of UKBM in other Indonesia by involving cadres Poskespan the balawista, and the involvement of puskesmas personnel for activities outside the health center.
Based on the result of the research, there is a tendency of decreasing the satisfaction of tourists after 6 months of model intervention in both groups (tourists visiting the existing beaches of Poskespan and tourists visiting the beaches where there is no Poskespan). It can be said that the satisfaction of tourists is influenced by the behavior of officers who work at Poskespan in terms of risk prevention and handling accident cases at the beach. Therefore, it is deemed necessary for the involvement of stakeholders, especially the Badung regency government (the health office and the tourism office of Badung Regency) in supporting the sustainability of the function of poskespan at the beach to conduct regular surf life saving training every year.

\section{References}

1. BPS (2017) Human Development Index. Jakarta.

2. Budhiana (2014) http://www.antaranews.com/berita. diakses, 27 November 2014.

3. Allender JA, Warner R (2014) Community \& Public Health Care. Lippincott Williams \& Wilkins.

4. Anderson ET, Mc Farlane JM (2011) Community as Parthner, theory \& Practice in Nursing. 6th edn., Lippincott Williams \& Wilkins: Philadelphia.

5. Lazzeretti L, Petrillo CS (2006) Tourism local systems and networking. Elsevier.

6. Kantawateera K, Naipinit A, Sakolnakorn TP, Kroeksakul P (2014) The satisfaction of tourists and policy guidelines for tourism development in Khon Kaen, Thailand. Asian Social Science 10: 53.

7. Supitchayangkool S (2012) The differences between satisfied/dissatisfied tourists towards service quality and revisiting Pattaya, Thailand. International Journal of Business and Management 7: 30.

8. Taylor A (2011) Using the GLM Procedure in SPSS. Department of Psychology, Macquarle University.

9. Rahman DKK (2013) Determinant of Community's Intention to Visit Posyandu. Jember.

10. Othman R (2011) Community Capacity Building for Sustainable Tourism Development, Experience from Miso Walay Homestay. Malaysia.

11. Guzman L, Canizares S, Pavon D (2011) Community Based Tourism in Developing Countries, a Case Study, Malaysia.

12. Nurhidayati SE (2012) Community-Based Sustainable Development Agro Tourism in Batu City, Jawa Timur.

13. Rad NF, Som AP, Zainuddin Y (2010) Service quality and patients satisfaction in medical tourism. World Applied Sciences Journal 10: 24-30.

14. Helmy EM (2011) Benchmarking the Egyptian Medical Tourism Sector against International best Practices: An exploratory study. An International Multidisciplinary Journal of Tourism 6: 293-311.

15. Chunlaka P (2010) International patients' satisfaction towards nurses service quality at Samitivej Srinakarin Hospital. Masters' Project cited by Srinakharinwirot University.

16. Platonova EA, Kennedy KN, Shewchuk RM (2008) Understanding patient satisfaction, trust, and loyalty to primary care physicians. Medical Care Research and Review 65: 696-712.

17. Kotler P (2003) Marketing Management, planning analysis, implementation and control. Jakarta, Prenhallindo.

18. Rahman DKK (2010) Foundations of Nursing in the Community: Community Oriented Practice. St Louis: Mosby.

19. Taie ES (2013) Emerging of Medical Tourism in Egyptian Hospitals: International Patient Satisfaction towards Nurses Services Quality. Global Advanced Research Journal of Management and Business Studies 2: 093-104. 